\title{
DOKUMENTTIELOKUVA MEDIAKASVATUKSEN TYÖKALUNA
}

\begin{abstract}
Dokumenttielokuva genrenä sijoittuu usein ihmisten mielikuvissa jonnekin uutisten ja fiktioelokuvien välimaastoon. Joillekin se saattaa olla todellisuuden taltiointia ja näyttämistä suoraan ja sellaisenaan. Toisille se on elokuvantekijän subjektiivinen näkökulma tai kokemus maailmasta. Kolmansille taas elokuva itsessään muovaa todellisuutta - oli se faktaa tai fiktiota. Yhteistä on kuitenkin ajatus dokumenttielokuvan erityisestä suhteesta todellisuuden kanssa. Katsauksessa dokumenttielokuvaa käsitellään mediakasvatuksen työkaluna, jonka avulla voi kehittää kriittistä medialukutaitoa, kriittistä ajattelua ja itsetuntemusta.
\end{abstract}

Dokumenttielokuvan, todellisuuden ja totuuden suhde on herättänyt keskustelua jo pitkään. Esimerkkeinä mainittakoon dokumenttielokuvan pioneerin John Griersonin määritelmä dokumenttielokuvasta todellisuuden luovana käsittelynä (ks. esim. Winston 2008, 9), ja elokuvateoreetikkojen Carl Plantingan ja Trevor Ponechin ajatukset dokumenttielokuvasta eräänlaisena sopimuksena katsojan ja tekijän välillä siitä, että elokuvassa esitetyt asiat ja väittämät ovat jollain tapaa tosia (Aaltonen 2006, 40). Kuitenkin esimerkiksi elokuvateoreetikko Brian Winston $(2008,14)$ kritisoi Griersonin lausahdusta kyseenalaistamalla paljonko "todellisuutta" on jäljellä "luovan käsittelyn" jälkeen. Moni elokuvantekijä korostaakin dokumenttielokuvan subjektiivista näkökulmaa tai dokumenttia omana taidemuotonaan.

Dokumenttielokuvan määrittely "vain" taiteeksi voi kuitenkin olla ongelmallista. Winston kuvailee, kuinka dokumentaristi on valikoiva, sen myötä luova, luovuuden myötä taiteellinen, ja taiteellisuuden myötä jossain määrin vapautunut moraalisista ja eettisistä normeista (Winston 2008, 29). Painotus taiteellisuuteen saattaakin kätkeä alleen esimerkiksi dokumenttielokuvan eettiset ja sosiaaliset ulottuvuudet.

Kuvan ja todellisuuden suhde on periaatteessa monimutkaistunut digitaalisten kuvatallentimien, kuvanmuokkausohjelmien ynnä muiden teknisten työ- ja apuvälineiden myötä. Ohjeet ja ohjelmistot sekä liikkuvan että pysähtyneen kuvan muokkaamiseen ovat nykyään lähes kaikkien ulottuvilla. Vaikka digitaalinen manipulaatio jätettäisiin keskustelun ulkopuolelle, jo kuvien rajaus tai valikointi jättää osan todellisuudesta huomioimatta tai piilottaa osia siitä. Tekijän tai tekijöiden fokus, ideologia ja ylipäätään käsitykset ja mielikuvat todellisuudesta vaikuttavat aina lopulliseen tekstiin teknisistä välineistä huolimatta (Rajala 2017, 20).

Odotukset tai vaatimukset jonkinlaisesta totuudenmukaisuudesta elävät kuitenkin sinnikkäästi dokumenttielokuvan, kuten myös esimerkiksi journalismin kohdalla (esim. Winston 2008; Rajala 2017). Tutkimuksessa, jossa kysyttiin, miten uutisten totuudellisuus ymmärretään, vaihtelivat vastaukset tai määritelmät suuresti. Suurimmalle osalle vastaajista se tarkoitti, että esitetty asia vastaa todellisuutta, toisille 
sitä, että väitteen tukena on tieteellistä teoriaa, kolmansille sitä, että yleinen mielipide puoltaa väitettä, tai joillekin yksinkertaisesti sitä, että esitetty väite "tuntuu" oikealta, eläväiseltä ja voimakkaalta (Andersson \& Weibull 2017, 107). Omassa arjessani kohtaankin monia ihmisiä, jotka suhtautuvat dokumenttielokuvaan uutiseen rinnastettavana tiedonlähteenä. Mutta totuudellisiksi luokiteltavien käsitysten ollessa myös uutisten kohdalla niin moninaisia, ei ajatusta dokumenttielokuvien vaikutusmahdollisuuksista katsojiin kannata sivuuttaa, eikä etenkään tulevien dokumenttielokuvantekijöiden koulutuksessa. Sosiaalisen konstruktionismin näkökulmasta sosiaalinen todellisuus myös rakentuu kommunikatiivisten käytäntöjen kautta (Berger \& Luckmann 1967). Meidän on siis tiedostettava mitkä asiat vaikuttavat näihin käytäntöihin ja opittava osallistumaan prosessiin itse, ja mediakasvatus on tässä tärkeässä asemassa.

Mediakasvatusta käsittelevissä keskusteluissa ja materiaaleissa nostetaan monesti esiin medialukutaito ja kriittinen ajattelu. Suomalaisten osaamista ylistetään jopa Atlantin toisella puolella viihdeohjelmissa, esimerkiksi Michael Mooren dokumenttielokuvassa Where to Invade Next (2015) ja keskusteluohjelmassa Full Frontal with Samantha Bee (2017). Mutta annetaanko näissä medialukutaidoistamme turhankin ruusuinen käsitys? Ainakin vielä muutama vuosi sitten uutisoitiin siitä, kuinka lukiolaisten medialukutaidon taso huolestuttaa opettajia (Salmirinne 2015). Osalle kriittisyys on helppoa, toiset oppilaat suhtautuvat hyvinkin kritiikittömästi mediasisältöihin. Aina opettajatkaan eivät ole täysin tietoisia siitä, mitä kriittinen medialukutaito sisältää, tai kuinka sitä pystyisi opettamaan (Hyytiä \& Saloranta 2015, 61). Myös Opettajaopiskelijat ja mediakasvatus 2017 -selvityksestä käy ilmi, että alle $40 \%$ vastaajista kokee, että heidän pakollisiin opintoihinsa sisältyy esimerkiksi kriittistä ja tutkivaa asennetta mediaa kohtaan tai informaation haku- ja lukutaitoa ja niiden opettamista (Salomaa \& al. 2017).

Tässä tekstissä pyrin avaamaan eroavaisuuksia kriittisen medialukutaidon ja muiden mediakasvatuksen teoreettisten lähestymistapojen välillä. Esittelen myös yhden esimerkin siitä, miten dokumenttielokuvaa voidaan hyödyntää käytännössä medianomiopiskelijoiden koulutuksessa.

On kuitenkin muistettava, että kriittinen pedagogiikka on mediakasvattajan vastuulla. Ilman tietynlaisen ajatusmaailman omaksumista, hän ei myöskään voi opettaa sitä. Kellner ja Share varoittavat $(2007,61)$, että osaamattoman käsissä medialukutaitoon keskittyvä opetus voi pahimmillaan olla eräänlainen keittokirja, joka tarjoaa vain omia reseptejään ja omanlaisia konventiotaan. Tästä syystä toivonkin, että katsaus voisi inspiroida erilaisten käytännön sovellusten suunnittelussa, ongelmakohtien kartoituksessa, ja esimerkiksi mediakasvattajan oman ammattifilosofian pohdinnassa.

\section{Kriittinen medialukutaito ja kriittinen pedagogiikka}

Ymmärtääksemme kriittisen medialukutaidon tärkeyden on hyvä kerrata tai tutustua muutamiin mediakasvatuksen teoreettisiin lähestymistapoihin. Mediakasvatusfilosofian professori Douglas Kellner ja kasvatustieteilijä Jeff Share (2007) luettelevat neljä lähestymistapaa: protektionistisen, taidekasvatuksellisen, medialukutaitoa korostavan ja kriittistä medialukutaitoa korostavan lähestymistavan. Protektionistisen mediakasvatuksen tavoitteena on suojella ihmisiä median manipulaatiolta ja riippuvuutta aiheuttavilta vaikutuksilta. Kirjoittajien mukaan tämä lähestymistapa asettaa median käyttäjän passiivisen uhrin asemaan ja vesittää mahdollisuuden voimaantumiselle (Kellner \& Share, 2007, 6). 
Taidekasvatuksellisessa lähestymistavassa opetetaan yleensä arvostamaan esteettisiä ominaisuuksia ja oppilaita käyttämään luovuutta itseilmaisussa. Tämänkaltainen opetus voi kuitenkin olla ongelmallista, jos individualistinen itseilmaisu korostuu liiaksi ja sosiaalinen ulottuvuus jää varjoon. Kirjoittajat kertovatkin kuinka monissa taidekasvatusohjelmissa oppilaat oppivat lähinnä toistamaan hegemonisia representaatioita, mutta eivät opi ymmärtämään näiden ideologisia implikaatioita eivätkä juurikaan sosiaalista kriittisyyttä. Vaikka oman äänen löytäminen ja mahdollisuus itseilmaisuun ovat tärkeitä asioita, nämä eivät riitä ilman kriittisiä taitoja. Itseilmaisu voi myös toimia sorron työkaluna, esimerkiksi rasististen ja seksististen näkemysten ilmaisuna (Kellner \& Share 2007, 60).

Kolmas, medialukutaitoa korostava lähestymistapa koostuu viestintätaitoja kehittävästä opetuksesta. Medialukutaidossa korostuu kyky hankkia, analysoida ja arvioida informaatiota sekä kyky kommunikoida itse. Vaikka nämä taidot ovat myös kirjoittajista tärkeitä, he kritisoivat lähestymistapaa muun muassa siitä, ettei siinä huomioida kielen ideologista ulottuvuutta ja valta-aspekteja. Se myös kätkee mediakasvatuksen muutospotentiaalin ja työkalut demokratian vahvistamiselle (ibid., 60-61).

Kirjoittajat ehdottavat puolestaan lähestymistavaksi kriittistä medialukutaitoa. Se yhdistelee osia edellä mainituista tavoista, kuten vaihtoehtoista mediatuotantoa ja analyysin yhteiskunnallista ulottuvuutta. Sen lisäksi siinä tarkastellaan, miten informaatio ja valta linkittyvät yhteen. Mediakuluttaja nähdään mallissa aktiivisena tulkitsijana, ja opetuksen tavoitteena on saada opiskelija ymmärtämään, kuinka tämä voi kriittisesti käyttää ja analysoida mediaa.

Kriittiseen medialukutaitoon liittyy tiiviisti kriittinen pedagogiikka, jonka kehittelijöiksi nimetään ainakin kasvatusfilosofit Paulo Freire ja John Dewey (Kellner \& Share 2007). Suomalaisessa kontekstissa viestinnän professori Juha Herkman on kirjoittanut paljon aiheesta. Kriittisen pedagogiikan piirteitä ovat muun muassa ideologioiden haastaminen, vallan tekeminen näkyväksi ja demokraattisten käytäntöjen luominen (Stocchetti 2015). Kriittisen pedagogiikan päätavoitteiksi Kellner ja Share nimeävät kriittiset reflektiotaidot ja toiminnan yhteiskunnan muuttamiseksi (Kellner \& Share 2007, 63). Herkmanin mukaan kriittisen mediakasvatuksen tulee ohjata oppilas kyseenalaistamaan ja ajattelemaan asioita monesta näkökulmasta (2007, 223). Opetus ei tapahdu perinteisessä mielessä ylhäältä alas, eikä saarnaa oikeaa tai väärää, vaan kumpuaa oppilaiden omista ajatuksista, kokemuksista ja arvoista (ibid.). Yhteiskunnallisessa mittakaavassa kriittisen medialukutaidon ja kriittisesti tiedostavan subjektin nähdään olevan välttämättömiä osallistuvalle demokratialle (participatory democracy; Stocchetti 2017; Kellner \& Share 2007, 59).

\section{Dokumenttielokuva mediakasvatuksessa, käytännön esimerkkinä Point of View -pilottihanke}

On epäilemättä olemassa monia tapoja soveltaa dokumenttielokuvaa opetustyössä. Muun muassa lapsille ja nuorille suunnattuun opetukseen löytyy suomeksi julkaistua materiaalia, esimerkiksi Antti Haarasen ja Virve Aholan oppaasta Meidän dokkari - yhteisöllisen dokumenttielokuvan menetelmä (2015). Oppaan harjoituksissa sekä keskustellaan dokumenttielokuvasta että harjoitellaan dokumentin tekemistä itse. Käytännön harjoittelu ja teknisten työkalujen ja taitojen kehittäminen opetuksessa ovat monella tapaa hyödyllistä. Työkalujen ja tekniikan hallitseminen myös edesauttaa miettimään samoja työkaluja kriittisemmin. Pahimmillaan se kuitenkin typistyy opettamaan opiskelijoita toisintamaan tietynlaisia representaatioita, tai mukautumaan jonkinlaiseen "poliittiseen korrektiuteen" kyseenalaistamatta asioita (Kellner \& Share 2007, 60, 67). 
Vastauksena tähän haasteeseen Ammattikorkeakoulu Arcadassa järjestettiin lukuvuoden 2015-2016 mittainen kokeellinen Critical Media Laboratory -kurssi ja pilottihanke Point of View. Kurssille osallistui pääasiassa Arcadan elokuva- ja televisiopuolen kolmannen vuoden opiskelijoita, joihin myös itse kurssiajankohtana lukeuduin. Kurssi koostui itsenäisestä työskentelystä ja epäsäännöllisistä lähiopetustilanteista, joissa pääosassa oli ryhmäkeskustelu. Tämä osio katsauksesta kysymyksineen pohjautuukin pääasiassa kurssilla käytyihin keskusteluihin, kuin myös pohdintoihini kurssin aikana ja sen jälkeisinä vuosina tähän päivään saakka.

Kurssilla kukin opiskelija valitsi itselleen tärkeäksi kokemansa aiheen. Tehtävänä oli tuottaa itsenäisesti (ei esimerkiksi ryhmätyönä) kolme "tekstiä". Yhtenä niistä oli lyhyt dokumenttielokuva, toisena "musta päiväkirja" - eräänlainen muistikirja, johon opiskelijat kirjoittivat ajatuksiaan prosessin kulusta, eikä päiväkirjan merkintöjä tarvinnut näyttää kenellekään. Kolmas oli essee, joka mustan päiväkirjan sijaan oli julkinen. Siinä olennaista oli perustella valintojaan ja päätelmiään tutkittavasta aiheesta.

Dokumenttielokuvan tekninen tai esteettinen toteutus, jotka usein korostuvat taidekasvatuksessa tai esimerkiksi elokuvaopiskelijoiden arvioinnissa, oli kuitenkin toisarvoista tai epäolennaista kurssiarvosanan kannalta. Sen sijaan opiskelijan oma ajatteluprosessi, ajatusten perustelut ja niiden kommunikointi korostuivat opiskelijaarvioinnissa. Tehtävien tavoitteina oli
a) ilmaista mielipide,
b) kehittää opiskelijoiden itsetuntemusta ja itsehavainnointitaitoja,
c) kehittää opiskelijoiden tuntemusta ympäröivästä sosiaalisesta maailmasta sekä
d) syventää opiskelijoiden viestinnällisiä valmiuksia.

Mielipiteen ilmaisu saattaa kuulostaa helpolta. Kuitenkin esimerkiksi marginalisoitujen ryhmien osalta tämä ei aina ole itsestään selvää, tai tekstin tuottaja saattaa muuten pelätä syrjityksi tulemista mielipiteensä tähden. Mielipiteen ilmaisua ei myöskään voi pitää itseisarvona, sillä mielipide saattaa olla myös esimerkiksi seksistinen tai rasistinen. Kasvatustieteilijät Ricky Lee Allen ja César Augusto Rossatto pohtivatkin artikkelissaan (2009) ongelmakohtia kriittisen pedagogiikan soveltamisessa etuoikeutettuun ryhmään kuuluvien oppilaiden kanssa ja kertovat esimerkiksi kohdanneensa vastarintaa opiskelijoiden taholta. Mediakasvatuksessakin olisi kuitenkin tärkeää ohjata etenkin etuoikeutettuun ryhmään kuuluvaa opiskelijaa kyseenalaistamaan mielipiteensä - onko se perusteltu, vai pelkkä asenne tai uskomus? Minkä varaan opiskelija rakentaa kyseisen asenteen tai uskomuksen? Mitkä ovat perusteet? Mitä kautta mielipide on muodostunut ja millaisessa yhteiskunnallisessa ja historiallisessa kontekstissa? Minkälaiset todisteet (tai dokumentit) tukevat tai eivät tue mielipidettä, kuka tai mikä taho ne tarjoaa, ja mitkä niiden tahojen intressit ovat? Millainen painoarvo näillä asioilla on meille itsellemme? Toisin sanoen, miten rakennamme oman totuutemme? Pelkäävän oppilaan kanssa voi lisäksi pohtia, onko pelko perusteltu ja miksi, tai rohkaisemaan tätä toimintaan eli tekstin tuottamiseen.

Nämä kysymykset kulkevat käsi kädessä jo tehtävän kahden seuraavan kohdan kanssa, eli oman itsensä ja sosiaalisen ympäristön tuntemisen ja havainnoimisen kehittämisen kanssa. Mitä tekijän lähipiiri ajattelee esimerkiksi koulutuksesta, uskonnosta, sukupuolirooleista tai vaikkapa lentävistä lautasista? Ja miten ajatus poikkeaa - vai onko se samankaltainen - muiden ihmisten näkemyksistä? Minkälaisia konflikteja on odotettavissa ja millaisten konfliktien kanssa tekijä itse kestää? Entä mitä vaikutuksia tekeillä olevalla dokumenttielokuvalla on muihin ihmisiin sen tekovaiheessa tai jos se julkaistaan. Entä onko tältä osin eroja lyhyellä tai pitkällä aikavälillä? 
Tekstin tuottaminen, olkoon se sitten dokumenttielokuvan tai esseen muodossa, on vuorostaan viestintätaitojen harjaannuttamista, mikä on tehtävän neljäs kohta. Tähän liittyy myös visuaalisen (ja audiovisuaalisen) viestinnän haastavuus, sillä se on usein perinteistä tekstiä monitulkintaisempi, puhumattakaan äänen vaikutuksista kokonaisuuden tulkintaan. Kuvat koivunoksista heilumassa kesäpäivänä saavat aivan erilaisia tuntemuksia aikaan riippuen siitä, soiko taustalla Olavi Virran "Kesäyön valssi" vai PMMP:n "Rusketusraidat" (minkä lisäksi pelkästään nämä kaksi musiikkiesimerkkiä herättävät eri lukijoissa hyvinkin erilaisia assosiaatiota). Entäpä samaiset koivunoksat muutamaa kuukautta aiemmin kurottamassa paljaina kohti aurinkoa?

Koivunoksat eivät todellisuuskäsityksiin paljoakaan vaikuta, mutta monesti dokumenttielokuvassa onkin kyse laajemmista yhteiskuntaan ja ihmisyyteen liittyvistä asioista, kuten terveydestä, politiikasta tai identiteetistä, jolloin audiovisuaaliset valinnat vaikuttavat yhtä lailla. Kykenenkö siis dokumenttielokuvan tekijänä välittämään oman totuuteni eteenpäin sen vääristymättä oman kömpelyyteni tai ajattelemattomuuteni vuoksi? Osaanko ottaa huomioon katsojan monet potentiaaliset tulkintatavat tekemälleni tekstille?

Nämä kysymykset ovat tärkeitä varsinkin dokumenttielokuvan tekijälle, mutta myös katsojan voi yhtä lailla haastaa miettimään näitä kysymyksiä. Miksi tietty dokumenttielokuva tuntuu katsojasta totuudellisemmalta kuin toinen? Mitkä asiat herättävät katsojan luottamusta, mitkä etäännyttävät? Mitkä asiat tukevat aiempia käsityksiämme ja mitkä haastavat ne? Entä missä määrin miellyttävä tai epämiellyttävä musiikki tai kuvallinen kerronta tempaa katsojan mukaansa, tai karkottaa? Vaikka mediakasvattaja ei sisällyttäisi dokumenttielokuvan käytännön toteutusta harjoituksiin opetusympäristössä, nämä kysymykset voivat olla hyödyksi jo silloin kun katsoo ja analysoi jonkun toisen luomaa tekstiä.

Haastavaksi dokumenttielokuvan pohdinta muuttuu muun muassa niin sanotun vahvistusvinouman takia, eli taipumuksen uskoa sisältöä, joka jollain tapaa vahvistaa ennakkokäsityksemme (Motturi 2016). Saatamme olla tiedostamattomasti valikoivia todisteiden suhteen tai tulkita niitä vääristyneesti. Myös siksi on tärkeää harjoitella itsereflektiotaitoja.

Point of View -kurssin musta päiväkirja -tehtävän hyödyt näkyivät ehkä parhaiten juuri itsereflektion harjoittelussa. Ainakin oman kokemukseni mukaan perinteinen oppimispäiväkirja, joka palautetaan kurssin loppupuolella ei tuota samankaltaisia hyötyjä, sillä sitä kirjoittaessa väistämättä joutuu pohtimaan lukijaa, eli viestin vastaanottajaa. Tällöin kirjoitusprosessista muodostuu ennemmin kommunikaatioharjoitus, mikä on toki myös tärkeää, mutta samanaikaisesti kirjoittaja saattaa sensuroida itseään ja siten myös jäädä paitsi monista oivalluksista sekä itsensä että ympäröivän maailman osalta. Myös ujo tai arempi oppilas voi saada itsestään irti enemmän, kun aivoituksia ei tarvitse antaa muiden riepoteltaviksi tai arvosteltaviksi. Nimenomaan arvostelun pelko voi olla todella vahingollista ja syödä oppimisintoa.

Aikaa taustatutkimukselle ja itsereflektiolle oli Point of View -projektissa sopivasti, koska prosessi ulottui kokonaisen lukuvuoden ajalle. Lähiopetustilanteet koostuivat lähinnä keskusteluista, joissa opiskelijoiden ajatuksia ja matkan varrella kohtaamia ongelmia puitiin ryhmässä. Ryhmä toimi tällöin heijastuspintana ja pystyi tarjoamaan sekä tukea että vaihtoehtoisia tulkintatapoja, ja haastamaan aiempia näkemyksiä. Koska kriittisen medialukutaidon ja kriittisen ajattelun opettelu on elinikäinen prosessi, ei kurssin tuloksia onnistumisen osalta voi mitata. Harjoituksena tai uudenlaisten ajattelumallien kylväjänä se ainakin toimi mitä parhaiten. 


\section{Kohti kriittistä tietoisuutta ja demokratiaan osallistumista}

Esittelin tässä katsauksessa teoreettisia lähestymistapoja mediakasvatukseen ja perustelin kriittisen medialukutaidon ja kriittisen mediapedagogiikan tärkeyttä. Tämän lisäksi nostin esiin esimerkkejä dokumenttielokuvan mediakasvatuksellisista työkaluista tai soveltamismahdollisuuksista etenkin kriittisen medialukutaidon ja -ajattelun tukemiseksi. Käytännön esimerkkinä toimi Point of View -hanke, joka oli suunnattu media-alan korkeakouluopiskelijoille. Katsauksellani pyrin myös tarjoamaan työkaluja, joita voi soveltaa muuhunkin kriittiseen mediakasvatukseen ja toisenlaisissa oppimisympäristöissä.

On myös syytä muistuttaa, että kriittinen pedagogiikka on lopulta mediakasvattajan itsensä vastuulla, ja se vaatii tietynlaisen ajatusmaailman omaksumisen. Pohdittavaksi jääkin, miten tämä onnistuisi? Kuten Kellner ja Share varoittavat (2007, 61), osaamattoman käsissä medialukutaidon opetus on pahimmillaan vain omanlaisia konventioitaan tarjoava reseptikirja. Loppujen lopuksi kyse ei ole siitä, että oppilaalla olisi pelkästään välineitä selviytyä koulumaailmassa, vaan tavoitteena on opastaa ihmisiä kriittiseen tietoisuuteen ja demokraattiseen osallistumiseen - antaa eväitä elämänmittaista matkaa varten.

Lisää Media and Education in the Digital Age -ohjelmasta luettavissa täällä: http://rdi. arcada.filmedalen/

\section{Lähteet}

Aaltonen, Jouko (2006) Todellisuuden vangit vapauden valtakunnassa: Dokumenttielokuva ja sen tekoprosessi. Helsinki: Like.

Allen, Ricky Lee \& César Augusto Rossatto (2009) "Does Critical Pedagogy Work with Privileged Students?". Teacher Education Quarterly, 36(1), 163-180.

Andersson, Ulrika \& Weibull, Lennart (2017) "Litar vi på medierna?". Larmar och gör sig till. Göteborgs universitet: SOM-institutet. Saatavilla: <https:/som.gu.se/digitalAssets/1649/1649011_097-112-andersson-o-weibull.pdf $>$ (linkki tarkistettu 11.8.2018)

Berger, Peter L. \& Luckmann, Thomas (1967) The Social Construction of Reality: A Treatise in the Sociology of Knowledge. New York: Doubleday.

Full Frontal with Samantha Bee. "Finnish Fake News | October 11, 2017 Act 3 | Full Frontal on TBS". YouTube. Saatavilla: <https://youtu.be/wwAzU5ji-CM> (linkki tarkistettu 18.3.2018).

Haaranen, Antti \& Ahola, Virve (2015) Meidän dokkari - yhteisöllisen dokumenttielokuvan menetelmä. Saatavilla: <http://www.kulttuurivalve.fi/tiedostot/Elokuvakoulu/PDF/Meidan_dokkari_web_2014-12-18. pdf> (linkki tarkistettu 8.7.2018)

Herkman, Juha (2007) Kriittinen mediakasvatus. Tampere: Vastapaino.

Hyytiä, Minna \& Saloranta, Sofia (2015) Luokanopettajien käsityksiälukemisesta, kriittisestä lukutaidosta ja niiden merkityksistä. Saatavilla: <http://urn.fi/URN:NBN:fi:jyu-201510193413> (linkki tarkistettu 30.3.2018).

Kellner, Douglas \& Share, Jeff (2007) "Critical Media Literacy: Crucial Policy Choices for a TwentyFirst-Century Democracy". Policy Futures in Education, 5(1), 59-69.

Motturi, Pauliina (2016) "Informaatiosota vastaan medialukutaito: Kenen lauluja laulat?". Me 6.9.2016. Saatavilla: <https://yle.fi/aihe/artikkeli/2016/09/06/informaatiosota-vastaan-medialukutaito-kenenlauluja-laulat> (linkki tarkistettu 21.3.2018).

Rajala, Anne (2017) Documentary Film, Truth and Beyond: On the Problems of Documentary Film as Truthtelling. Saatavilla: <http://urn.fi/URN:NBN:fi:amk-201705117808> (linkki tarkistettu 18.3.2018).

Salmirinne, Sini (2015) "Toiset ovat kriittisiä, toiset uskovat kaiken - lukiolaisten medialukutaidon taso huolestuttaa opettajia". Me 17.4.2015. Saatavilla: <https://yle.fi/uutiset/3-7932419> (linkki tarkistettu 30.3.2018) 
Salomaa, Saara; Palsa, Lauri; Ville Malinen (2017) Opettajaopiskelijat ja mediakasvatus 2017. Kansallinen audiovisuaalinen instituutti. Saatavilla: <http://www.mediataitokoulu.fi/opettajaopiskelijat.pdf $>$ ja $<$ http://www.mediataitokoulu.fi/liiteselvitykseen/> (linkit tarkistettu 11.8.2018)

Stocchetti, Matteo (2015) "Critical Pedagogies \& Film Education in Neoliberal Times: Notes for Educators who Haven't Given Up". Critical Pedagogies in Neoliberal Times / Cinema Journal Teaching Dossier Vol. 3 (2). Saatavilla: <http://www.teachingmedia.org/critical-pedagogies-film-education-in-neoliberaltimes-notes-for-educators-who-havent-given-up/> (linkki tarkistettu 25.6.2018)

Stocchetti, Matteo (2017) "Persona \& Parrhesia: Research Notes On the Dialectics of the Real". Persona Studies 3.2: 79 .

Where to Invade Next (2015). Ohjaus: Michael Moore. Dog Eat Dog Films \& IMG Films. 